\title{
Lean Manufacturing and Work Study: Analysis and Integration in an Outbound Logistics Case Study Yotsuda Buranasing and Juthamas Choomlucksana
}

Materials Handling and Logistics Engineering Department, King Mongkut's University of Technology North Bangkok, 1518, Pracharat 1 Rd., Wongsawang, Bangsue, Bangkok, 10800, Thailand

\begin{abstract}
Lean manufacturing and work study are both popular and have been widely applied to achieve quality and productivity improvement in several industrial sectors (automotive, health care, and etc.) with high success. Previous studies found that some researchers apply lean manufacturing techniques only, whereas others apply only work study. But not all, some studies have used both techniques for productivity improvement. Therefore, a number of questions remain concerning the gap between the applications of these two techniques. The aim of this research is to fill the gap between these two techniques by reviewing the relationships, differences, and similarities between these two techniques; the results of the two techniques' applications to real case, studies and outbound logistics activities will also be reviewed. A literature review has been conducted to gain an overview of both techniques. Moreover, the case study have shown that both techniques demonstrate enhanced productivity performance. The case study results indicate the relationships, differences, and similarities between the techniques and the benefits of each. In fact, lean manufacturing techniques provide a good overview of processes, whereas the work study techniques focused on critical areas. The effects of applying these techniques are contrasted. Finally, time spent and cost were reduced at the outbound logistics stations.
\end{abstract}

Key words: Productivity improvement, Work study, Lean manufacturing, outbound logistics

\section{INTRODUCTION}

As the competitive business is relatively high. Companies must find ways to develop business in order to increase competitiveness and sustainable business practices. An important factor is the ability to use analysis technique to reduce either non-value-added activities or necessary non-value-added activities in manufacturing processes. It is known that logistics cost is the highest cost for every factory. The data from the Logistics Committee of the National Economic and Social Development Board, Thailand [1] in 2015 showed that the highest logistics cost are from shipping and inventory as shown in figure 1 .

Generally, lean manufacturing and work study techniques have been widely used in helping productivity and quality improvements. Moreover, each technique has a slightly different aim. Lean manufacturing techniques are commonly used to identify and eliminate seven or eight wastes, whereas the principles of work study technique improve workers' process and eliminate unnecessary time spent on work tasks.

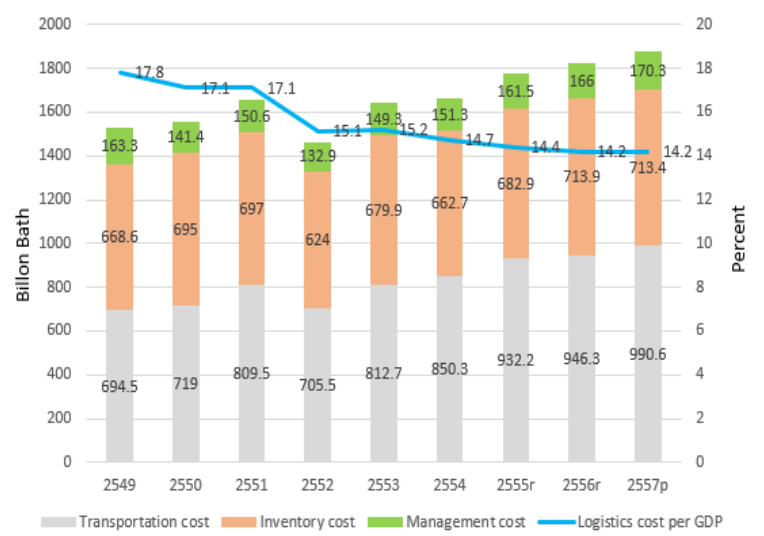

Fig 1 Thailand logistics cost per GDP in 2015

Corresponding Author: Juthamas Choomlucksana, Dept. of Materials Handling and Logistics Engineering, 1518, Pracharat 1 Rd., Wongsawang, Bangsue, Bangkok, 10800, Thailand, Cell phone: +66-25874350 
Furthermore, lean manufacturing techniques are not new; they are derived from the Toyota Production System (TPS). Lean manufacturing techniques are known in 1990 from the book "The Machine That Changed the World" by Womack, Jones and Roos [2] which talked about the history and comparative study of automotive manufacturing among the Japanese, American, and European. Lean manufacturing techniques focus on eliminating non- value-added activities by looking for seven wasteful activities, thus creating continuous improvement in production flow. All activities in lean manufacturing philosophy are classified into two groups: value-added activities and non-value-added activities. Womack and Jones [3] stated waste as "any process that does not deliver value to the customer." The Seven waste activities consists of: waste of defects, waste of overproduction, waste of waiting, waste of non-utilized talent, waste of unnecessary transportation or excessive transportation, waste of excess inventory, waste of unnecessary motion, and waste of inappropriate processes or extraprocessing, which can be referred to as "Downtime." The principle of lean manufacturing techniques consist of five simple objectives: (1) identify a customer value by eliminating anything that does not add value to from the customer's perspective, (2) map the value stream as a picture of the overall process, (3) create flow by moving a product or people through a service process, (4) establish pull, and (5) seek perfection by continuously improving the process. Lean manufacturing is a set of techniques and tools for systemically analyzing processes and eliminating wastes. Value Stream Mapping (VSM), 5S, PokaYoke, Kaizen, etc. are among the most popular lean manufacturing tools to understand and improve a process. Researchers have applied lean manufacturing tools and techniques across the manufacturing and product development industries with high success. For example, Romon and Sherif [4] have applied the concepts of lean manufacturing techniques for construction performance improvement. The results showed that the waste in construction was identified and minimized; moreover, the factory has a future planned to apply lean manufacturing techniques to improve in other areas as well. Similarly, Rohac and Januska [5], Rahani and Muhammad [6], and Jafri and Seyed [7] use the VSM to improve manufacturing work flow. The VSM helps the factory identify areas with problems and see where the biggest bottleneck is throughout the organization. Azizi and Manoharan [8] applied the VSM and Kaizen activity with Single Minute Exchange of Die (SMED) to reduce the production lead time in Small Medium Enterprise (SME). An insertion process was identified as a bottleneck of the SME by using the VSM. A study found that there were about 13 internal activities during the Surface Mounting Technology setup at the insertion line. To achieve better productivity, SMED and quick changeover as lean tool were implemented at the insertion line by separating the internal from the external setup operations. Results showed that the number of setup tasks were reduced from 13 to 7 tasks, about $63 \%$ reduction in changeover. Thus, the machine setup time was reduced from 145 seconds to 54 seconds in the insertion production process.

In contrast, work study has been also used broadly in industries. Several claimed that work study can be applied to many service sector firms, with equally the impressive results achieved in the manufacturing sector. Similarly David and Federico [9] and Gabriela, Lili and David [10] also confirmed that the lean approach can be applied to service industrial. Method study and work measurement are the two major segments of work study. Based on the study by Moktadir, Ahmed and Fatema [11], work study has a positive relationship with reducing the production time of ladies' bags. A concept of asking questions and recording the amount of time in each workstation was applied. The research results proved that using work study techniques helps company to improve the process productivity by $12.71 \%$. Moreover,Bjorge et al, [12] found that work study has also helped to reduce waiting time in the manufacturing process and also reduced the time taken to deliver the product to the customers. Previous studies have shown that work study technique could be applied in many industries to improve productivity and customer satisfaction [13]. The number of successful work study implementations has been extensive [14-16].

On the other hand, several studies have been applied both techniques and have shown that there is a relationship between lean manufacturing and work study for productivity improvement. For example, Nonglucksana [17] applied lean manufacturing and work study techniques have applied lean manufacturing techniques to reduce waste caused by excess inventory and overproduction in the warehouse, but also use ECRS, which is one of the work study techniques. It is likely that lean techniques were implemented with a flow process chart (a work study 
technique) together to maximize production efficiency. Moreover, a combination of lean manufacturing and work study (flow process chart, man-machine process chart, and etc.) are used together for an efficient improvement in factory productivity [18]. On the other hand, Picet and Sukarnda [19] applied work study techniques with Yamazumi chart which is a technique associated with lean manufacturing in factory production process. Besides, both techniques can be effective for productivity improvement; lean manufacturing and work study techniques are types of improvement concepts. At times, it is difficult to say whether some techniques are lean manufacturing or work study. Although there are similar concepts between these two techniques, both have some differences between them.

This aim of this paper is twofold; (1) to fill the gap between lean manufacturing and work study techniques by reviewing the relationships, differences, and similarities of these two techniques; and (2) to present the results of applying both techniques to outbound logistics activities, in a real case study. The paper begins by providing the similarities and differences between the two techniques, lean manufacturing and work study. Later, the possible results influence on company productivity after implement both techniques are presented in a real case study, using outbound logistics. Moreover, the gap, both techniques from different disciplines is investigated.

\section{EXPERIMENT}

\section{Lean Manufacturing and Work Study Analysis}

To achieve this aim, a conceptual discussion of lean manufacturing and work study similarities and differences is presented. The first step of this process is to review the previous literature on lean manufacturing and work study techniques, as shown in the table below.

Table 1. Summaries benefits and main focus by using either lean manufacturing or work study from Literature Review.

\begin{tabular}{|c|c|c|}
\hline $\begin{array}{l}\text { Author and } \\
\text { publication year }\end{array}$ & Technique used & Benefits and main focus \\
\hline $\begin{array}{l}\text { Sumit et al [20], } \\
\text { Abdul and Tan } \\
\text { [21], Vincent, } \\
\text { Kitty and } \\
\text { Monique [22] }\end{array}$ & Lean Manufacturing & $\begin{array}{l}\text { Identification and Elimination of wastes through continue Improvement } \\
\text { and increased production efficiency }\end{array}$ \\
\hline $\begin{array}{l}\text { Rebecca and } \\
\text { Aile [23] }\end{array}$ & Lean Manufacturing & Improve productivity and reduced WIP (Work in-process). \\
\hline $\begin{array}{l}\text { Malihe et al } \\
{[24]}\end{array}$ & Lean Manufacturing & Elimination of waste, time, cost, and human resources needed. \\
\hline $\begin{array}{l}\text { Kevin, Darwin } \\
\text { and John [25] }\end{array}$ & Lean Manufacturing & Reduced time, unnecessary inventory, and factory space. \\
\hline Jostein $[26]$ & Lean Manufacturing and TQM & Increased productivity by using continuous improvement concepts. \\
\hline $\begin{array}{l}\text { Sharma et al, } \\
{[27]}\end{array}$ & Lean Manufacturing & $\begin{array}{l}\text { Elimination waste, reduced lead time and set-up time, and lower inventory } \\
\text { carrying cost. }\end{array}$ \\
\hline $\begin{array}{l}\text { Cengiz, Aysel } \\
\text { and Yunus [14] }\end{array}$ & Work Study & Increased productivity. \\
\hline $\begin{array}{l}\text { Amol and } \\
\text { Prabhakaran } \\
\text { [15] }\end{array}$ & Work Study & Reduced worker idle time, increased labour productivity, and productivity. \\
\hline
\end{tabular}

The results of preview literature review found the linkage between lean manufacturing and work study. Both lean manufacturing and work study can be effective for productivity improvement. Lean manufacturing technique mainly focuses on identifying and eliminating seven activities of waste, whereas the work study technique focuses on reducing the production time and eliminating nonproductive process. Figure 1 shows a comparison of lean manufacturing and work study techniques regarding previous studies. According to figure 1, Lean manufacturing and Work study intersect on worker and process which focused on non-value added activities including processing, motion, people utilization, waiting, and transportation. 


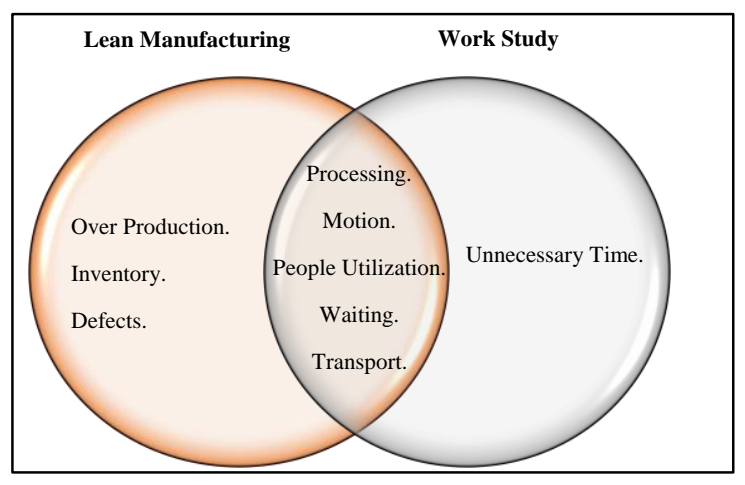

Fig 1. Similarity and differences of main focused on each technique.

Moreover, both techniques bring special attention and unique tools help company to clarify solutions according to its areas of focus and interest. As each technique has a common goal which has the primarily focus on the particular problem areas. Additionally, not only lean manufacturing, but also work study technique has its own tools regarding non-value added activities (discussed in figure 1) that depend on its focus and interest, as shown in the table 2 .

Table 2. Summarized of all general lean and work study tools used for solving each non-value-added activities.

\begin{tabular}{|c|c|}
\hline Lean Manufacturing & Work study \\
\hline \multicolumn{2}{|c|}{ Tools for analyze the processes } \\
\hline $\begin{array}{l}\text { Value Stream Mapping (VSM), Yamazumi Chart, Takt } \\
\text { time, Line balancing, Gemba }\end{array}$ & $\begin{array}{l}\text { Process Charts, Operation Process Charts, Flow Process Charts, } \\
\text { Assembly Process Chart, Multi-Product Process Chart, Travel Chart, } \\
\text { Multiple Activity Chart, Man-Machine Chart, Gang Process Chart, } \\
\text { Operation Chart }\end{array}$ \\
\hline \multicolumn{2}{|c|}{ Tools for reducing waste of ineffective process } \\
\hline $\begin{array}{l}\text { 5W1H, Standardized Work, Scheduling, Cellular } \\
\text { Manufacturing, 5S }\end{array}$ & Why-Why Analysis, ECRS, Plant Layout \\
\hline \multicolumn{2}{|c|}{ Tools for reducing waste of motions } \\
\hline $\begin{array}{l}\text { 5W1H, Standardized Work, Visual Control, } \\
\text { Cellular Manufacturing, 5S }\end{array}$ & $\begin{array}{l}\text { Why-Why Analysis, ECRS ,Plant Layout ,Flow Process Charts, Two } \\
\text { handed Chart, Multiple Activity Chart, Simo Chart, String Chart, } \\
\text { Predetermined Motion-Time System }\end{array}$ \\
\hline \multicolumn{2}{|c|}{ Tools to reducing waste of unutilized people } \\
\hline 5W1H, Multi-Tasking Skill & $\begin{array}{l}\text { Why-Why Analysis, Process Charts, Operation Process Charts, Flow } \\
\text { Process Charts, Multi-Product Process Chart, Two handed Chart, } \\
\text { Multiple Activity Chart, Man-Machine Chart, Operation Chart }\end{array}$ \\
\hline \multicolumn{2}{|c|}{ Tools to reducing waste of waiting } \\
\hline $\begin{array}{l}\text { 5W1H, Multi-Tasking Skill, Single Minute Exchange Of } \\
\text { Dies, Leveling, One-Piece Flow, Total Productive } \\
\text { Maintenance, Poka-Yoke, Cellular Manufacturing, 5S }\end{array}$ & $\begin{array}{l}\text { Why-Why Analysis ,ECRS, Process Charts, Operation Process } \\
\text { Charts, Flow Process Charts, Multi-Product Process Chart, Two } \\
\text { handed Chart, Multiple Activity Chart, Man-Machine Chart, Plant } \\
\text { Layout, Flow Diagram }\end{array}$ \\
\hline \multicolumn{2}{|c|}{ Tools to reducing waste of transportation } \\
\hline 5W1H, One-Piece Flow, Cellular Manufacturing, 5S & $\begin{array}{l}\text { Why-Why Analysis, Process Charts, Operation Process Charts, Flow } \\
\text { Process Charts, Man-Machine Chart, Travel Chart, Plant Layout, } \\
\text { Flow Diagram }\end{array}$ \\
\hline \multicolumn{2}{|c|}{ Tools for reducing waste of unnecessary inventory. } \\
\hline $\begin{array}{l}\text { 5W1H, Pull, Kanban, Buffer/Safety Stock, Visual } \\
\text { Control, 5S }\end{array}$ & - \\
\hline \multicolumn{2}{|c|}{ Tools for reducing waste of defects } \\
\hline $\begin{array}{l}\text { 5W1H, Standardized Work, Multi-Tasking Skill, } \\
\text { One-Piece Flow, Poka-Yoke, Jidoka }\end{array}$ & 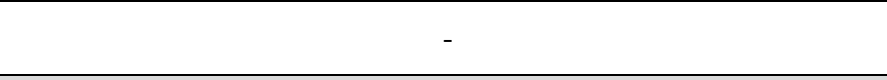 \\
\hline \multicolumn{2}{|c|}{ Tools for reducing waste of overproduction } \\
\hline 5W1H, Multi-Tasking Skill, One-Piece Flow, Pull & 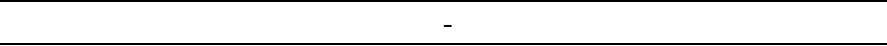 \\
\hline \multicolumn{2}{|c|}{ Tools for reduce waste of ineffective time } \\
\hline 5W1H, Single minute of die (SMED), TPM & Flow process chart, Why-why Analysis, ECRS \\
\hline
\end{tabular}

\section{Case Study: factory an application of Lean Manufacturing and Work Study}

The factory was selected as a case study due to its problems in logistics. As mentioned earlier, logistics activities have a higher cost compared to other activities. The major problems faced by the factory at the outbound logistics are analyzed. The outbound logistic deals with how factories get products to the customers. The factory is a lead manufacturer of industrial laminate, producing different sizes and weights of goods. The production line and warehouse are connected, as well as the packaging and delivery sections. Through observing production- 
site, found that warehouse department especially in the packing process was the bottleneck in the overall production process. As Rasi and Rakiman [28] stated that "reduction in the waiting time is an important element for increasing productivity." Then, techniques, lean manufacturing and work study are required to install for helping improve the productivity for each of these logistics areas. Analytical procedures are used to examine relationships between both techniques and their performance in the case study as follows.

1. Investigation of current activities related to outbound logistics of the case study.

2. Determine the areas where accumulation and bottlenecks occur in the warehouse production process. 3. Apply both techniques for each improvement step.

\section{RESULTS: Comparison and Case Study}

In short, the main focused point of this research is to present the integration results (Similarity and differences) of each technique and to reduce time spent in outbound logistics area. Firstly, the current state of the workflow in the outbound logistics of the case study is investigated. In this case, a warehouse department was selected from all outbound logistics departments because the department had high idle time that may cause bottleneck or waste. The warehouse department consists of the following activities: sorting products, storage products, picking, packing, preparing products, and delivery products to the customers. Next, both techniques (lean manufacturing and work study) were applied for each improvement step as follows:

\section{step1: Investigation of current activities related to outbound logistics of the case study:}

First, lean technique (including VSM, Takt time, and Yamazumi Chart tools) and work study technique (including Operation Chart, Flow Process Chart, and Flow Diagram tools) were applied for identifying problems and finding wastes. Figures 3, 4, and table 3 below show an example of both techniques used in the analysis process.

\section{Lean Manufacturing Technique}

1. VSM: VSM was used to analyze and improve the flow of factory information or materials that required producing the products in outbound logistics case study.

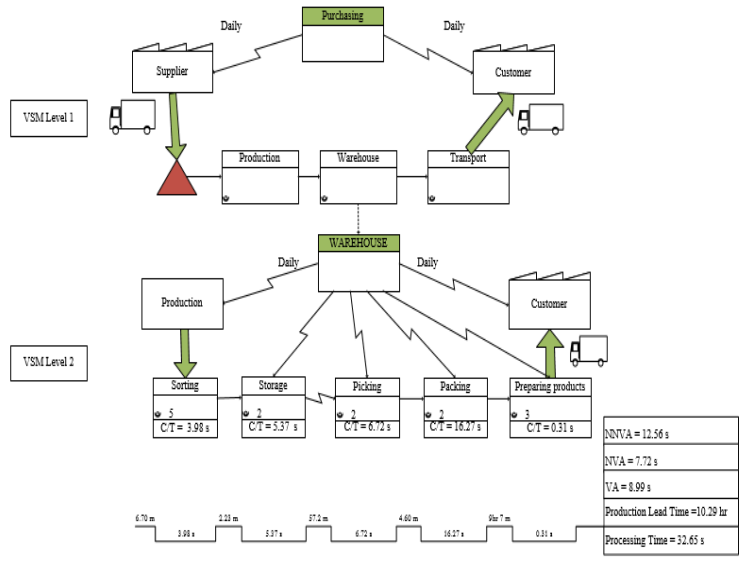

Fig 2 Shows VSM of case study for identifying current process (step 1)

2. Takt time and Yamazumi chart: These were used to investigate work details, flow, and time.

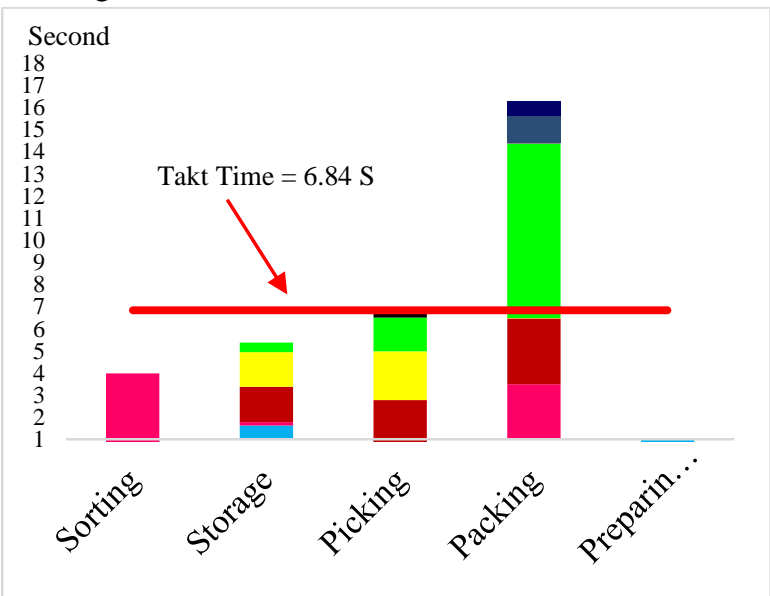

Fig 3 Shows Takt time and Yamazumi Chart for analyzing work at each station.

\section{Work Study Technique}

1. Operation Chart and Flow Process Chart: The activity details of each step in the outbound logistics, including time, distances, and quantity, were identified. An example of Flow Process Chart that used to visualize the movement within the warehouse department shows in Figure 4. 


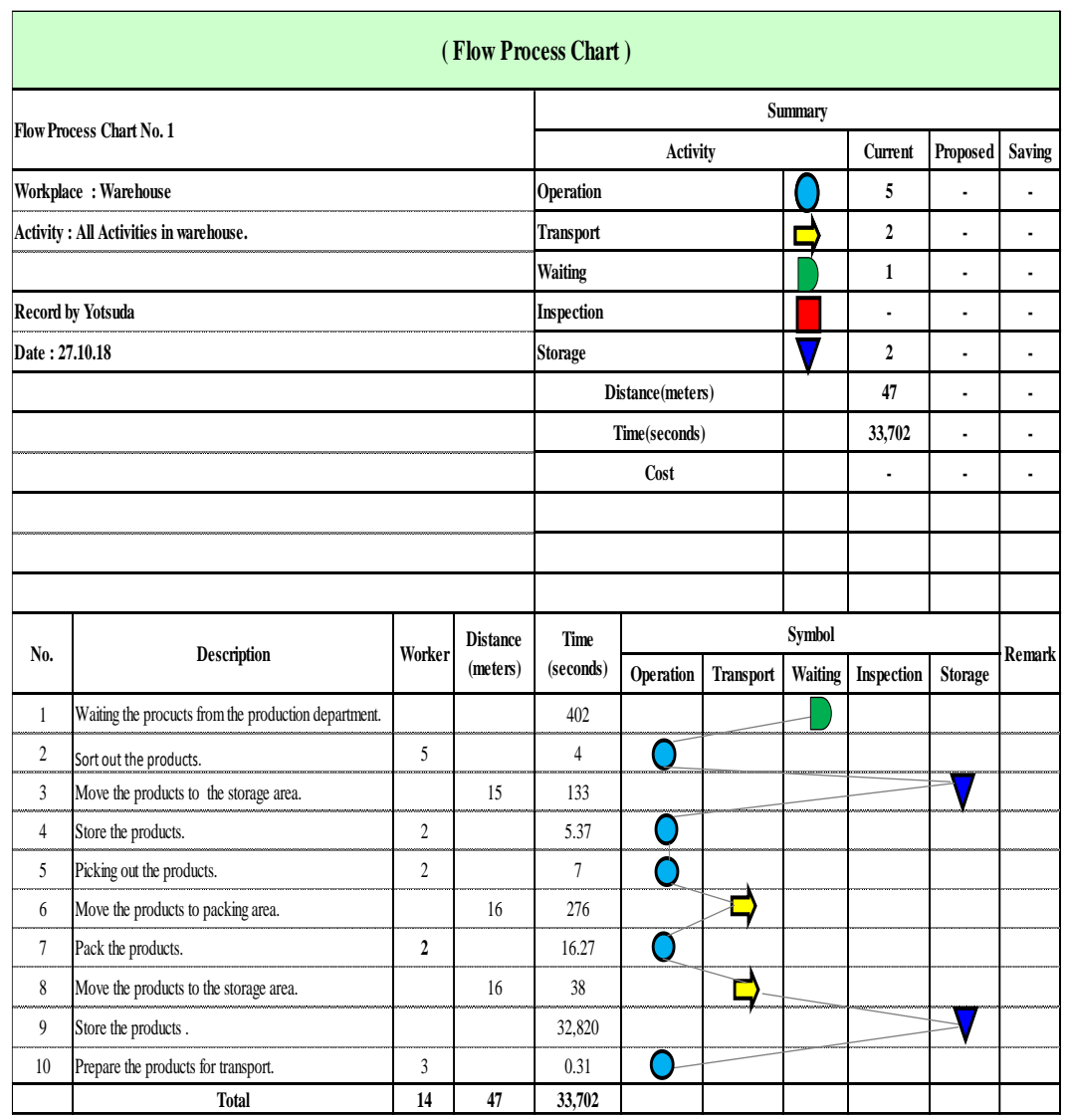

Fig 4 Shows an example of flow process chard used at the Analyze Process

Therefore, the data shows similar results by using both techniques (lean manufacturing and work study), however, there are slightly different between both techniques and the gap of tools for each technique results between these two techniques shown in table 3 .

Table 3 Summarized the gap of tools for analyze the processes between lean manufacturing and work study techniques.

\begin{tabular}{|l|l|l|}
\hline \multicolumn{1}{|c|}{ Technique } & \multicolumn{1}{|c|}{ Lean Manufacturing } & \multicolumn{1}{c|}{ Work Study } \\
\cline { 2 - 3 } Gap & $\begin{array}{l}\text { VSM, } \\
\text { Takt time, and } \\
\text { Yamazumi Chart }\end{array}$ & $\begin{array}{l}\text { Operation Process Chart, } \\
\text { Flow Process Chart, and } \\
\text { Flow Diagram }\end{array}$ \\
\hline Similarities & $\begin{array}{l}\text { Process overview and number of workers. } \\
\text { - Using symbol or graphic to identify work. } \\
\text { - Both tools help to identify the warehouse department into the five processes in outbound } \\
\text { logistics, whereas the Flow Process Chart provides more details of the process distance used for } \\
\text { completing an activity at the warehouse process. }\end{array}$ \\
\hline Differences & $\begin{array}{l}\text { Operation Process Chart provides only process flow and process overview not production detailed } \\
\text { (e.g. processing time, lead time, number of workers, and inventory). } \\
\text { - VSM helps the factory distinguish the value-added activities from non-value added or necessary } \\
\text { non-value added activities in the process. The Yamazumi chart provides a working balance, } \\
\text { whereas the Flow Process Chart identifies the activities at each step. } \\
\text { - Takt time helps the factory knows the available working time and demand requirements per day. }\end{array}$ \\
\hline
\end{tabular}

Step 2: Determine the areas where accumulation and bottlenecks occur in the warehouse process:

In general, the bottlenecks areas had been identified before the productivity was improved. In this case, only lean manufacturing tool, line balancing, was applied to investigate the inefficiencies process (cycle times or bottlenecks) where the load cycle time higher than takt time. 


\section{Lean Manufacturing Technique}

1. Line Balancing: This tool is used to categorize the overall process flow at the warehouse department. There is, however, only one technique, the line balancing tool was used. Line balancing was used to investigate all operational times whether all operational times were balanced and under the takt time in order to meet production demands. Fig 5 shows the line balancing tool in the warehouse production process for identifies bottleneck. The time which has longest cycle times and that has higher cycle time than the takt time is called the bottleneck process. It turned out that the packing products process is the bottleneck in the warehouse process.

\section{Step 3: Apply both techniques for each improvement step:}

Step 3 is to identify processes or activities that do not add value to the packing process and to identify the cause of the bottleneck, then find the potential solutions to get work flowing in packing products process by using lean manufacturing and work study techniques. There are a wide variety of tools which can be used to enhance the warehouse department productivity. Therefore, the following table shows the differences tools for both techniques used to identify and solve the causes of the bottleneck problems in the packing products process.

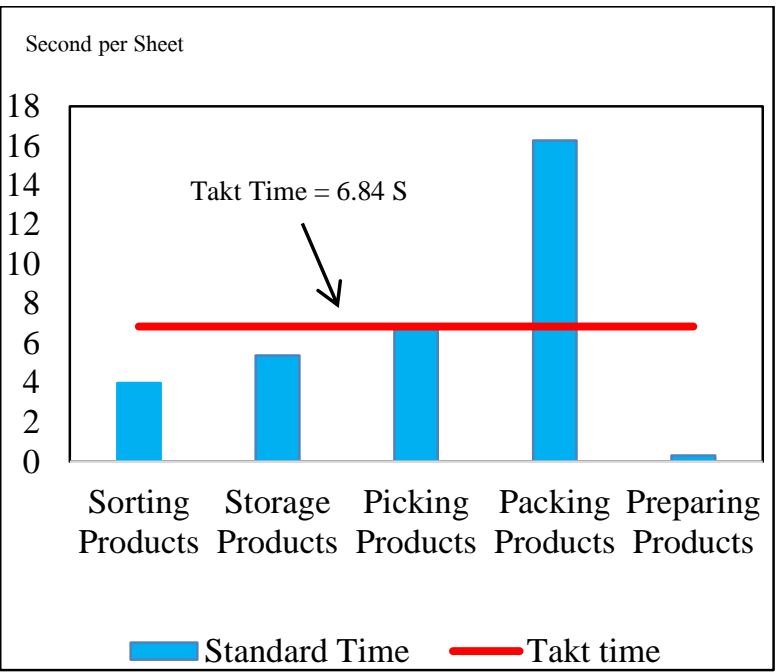

Fig 5 Shows Line balancing for identifies the bottleneck are

In short, lean manufacturing and work study techniques have the different perspective, tools and methodologies that are different covering problems for improve productivity as shown in table 7. For example, in this case, packing operators waited for the forklift delivery empty boxes from storage to packing area because there was no delivery service scheduling and the operators did not know the floor stock for each area, which causes a delayed delivery. Lean manufacturing tools including $5 \mathrm{~W} 1 \mathrm{H}$ and Poka-Yoke were used to indicate when do forklift delivers need to move the empty boxes to the packing areas. Moreover, stock replenishment and delivery scheduling were set by repeatedly asking the question "why" five times with the manager and operators at the problem areas.

Table 6 Summarized the difference tools used to solve each problem that cause bottleneck.

\begin{tabular}{|l|l|l|}
\hline \multicolumn{1}{|c|}{ Problem found } & \multicolumn{1}{c|}{ Tools for productivity improvement } \\
\cline { 2 - 3 } & \multicolumn{1}{|c|}{ Lean manufacturing } & \multicolumn{1}{c|}{ Work study } \\
\hline $\begin{array}{l}\text { Packing operators were waiting for a forklift delivery the packages (empty } \\
\text { boxes) from storage to packing areas. }\end{array}$ & $\begin{array}{l}\text { Cellular manufacturing } \\
5 \mathrm{~W} 1 \mathrm{H}, 5 \mathrm{~S}, \text { Poka-yoke }\end{array}$ & $\begin{array}{l}\text { Plant Layout } \\
\text { Why- Why Analysis }\end{array}$ \\
\hline $\begin{array}{l}\text { Packing operators were waiting for a forklift delivery the lift covers from } \\
\text { storage to packing areas. }\end{array}$ & $\begin{array}{l}\text { Cellular manufacturing } \\
5 \mathrm{~W} 1 \mathrm{H}, 5 \mathrm{~S}, \text { Poka-yoke }\end{array}$ & $\begin{array}{l}\text { Plant Layout } \\
\text { Why- Why Analysis }\end{array}$ \\
\hline $\begin{array}{l}\text { Packing operators were waiting for a forklift delivery the products from } \\
\text { picking area to storage areas. }\end{array}$ & $\begin{array}{l}\text { Cellular manufacturing } \\
5 \mathrm{~S}, 5 \mathrm{~W} 1 \mathrm{H}\end{array}$ & $\begin{array}{l}\text { Plant Layout, ECRS } \\
\text { Why- Why Analysis }\end{array}$ \\
\hline $\begin{array}{l}\text { Packing operators were required to move between the working table and } \\
\text { product preparation and packing area several times while packaging } \\
\text { products. }\end{array}$ & $\begin{array}{l}\text { Cellular manufacturing } \\
5 \mathrm{~S}, 5 \mathrm{~W} 1 \mathrm{H}\end{array}$ & $\begin{array}{l}\text { Plant Layout, ECRS } \\
\text { Why- Why Analysis }\end{array}$ \\
\hline $\begin{array}{l}\text { Packing operators made a mistake by putting the products to the wrong } \\
\text { customer's package. }\end{array}$ & $\begin{array}{l}5 \mathrm{~W} 1 \mathrm{H}, \text { Poka-yoke } \\
\text { (Self-inspection) }\end{array}$ & Why- Why Analysis \\
\hline $\begin{array}{l}\text { Forklift drivers often drove backwards from warehouse to storage area } \\
\text { several times a day. }\end{array}$ & $\begin{array}{l}\text { Cellular manufacturing } \\
5 \mathrm{~S}, 5 \mathrm{~W} 1 \mathrm{H}\end{array}$ & $\begin{array}{l}\text { Plant Layout } \\
\text { Why- Why Analysis }\end{array}$ \\
\hline
\end{tabular}


Juthamas Choomlucksana / Journal of Engineering and Science Research, 2(2) 2018, Pages: 17-25

Table 7 Gap between lean manufacturing and work study techniques for productivity improvement.

\begin{tabular}{|l|l|l|}
\hline \multirow{2}{*}{ Technique } & Lean Manufacturing & Work Study \\
\cline { 2 - 3 } Similarities & 5W1H, Cellular manufacturing, 5S, Poka-Yoke & Why-Why Analysis, Plant Layout, ECRS \\
\hline Differences & $\begin{array}{l}\text { - Identify main root cause of each problem } \\
\text { why, and how, whereas the Why-Why Analysis was used to investigate main root cause by using } \\
\text { open-question. }\end{array}$ \\
& $\begin{array}{l}\text { Both Cellular manufacturing and 5S focus on work station, moreover 5S helps to identify and } \\
\text { eliminate wastes. However, Plant Layout focuses on layout overview. }\end{array}$ \\
& $\begin{array}{l}\text { Jidoka and Poka-Yoke are used to detect and prevent errors while ECRS aims to make work } \\
\text { easier. }\end{array}$ \\
\hline
\end{tabular}

\section{CONCLUSION}

As a conclusion, lean manufacturing and work study are very effective used at productivity improvement with the factory. Both techniques have similar steps, tools and focuses in factory improving. Several tools from both techniques were applied to improve factory such as, VSM, Flow Process Chart, Poka-Yoke, Cellular manufacturing (U-shape cell and 5s), plant layout, ECRS, and etc. In this research study, the significant results after implemented lean manufacturing and work study were shown. The waiting time at the bottleneck area was reduced from 7.72 seconds per sheet to 2.15 seconds per sheet or by $72.15 \%$. Moreover, the motion time was reduced from 7.82 seconds to 6.53 seconds or by $17.54 \%$. The distance for packing products reduced from 27.45 meters to 16 meters or by $58.28 \%$. The average employee cost reduced by $0.32 \%$ with using both techniques together. Furthermore, results the gap between lean manufacturing and work study techniques. As lean manufacturing is focused on the overall process improvement and increasing flow of the process, similarly [29]. In contrast, work study looks for each job process improvement, which is accordingly consistent with previous research. Moreover, although there is agreement in previous studies that either lean manufacturing or work study techniques are the best, both techniques are more effective when used together. There is still a key difference between them.

\section{ACKNOWLEDGMENTS}

This research was partially supported by the Graduate Thesis Research Grant (GTRG) from the Graduate College, King Mongkut's University of Technology North Bangkok under award number 37 /fiscal year 2561.

\section{REFERENCES}

[1] Office of the National Economic and Social Development Board .2015. Thailand's Logistics
Report 2015. Bangkok: Office of the National Economic and Social Development Board (NESDB).

[2] Womack, J.P., Jones, D.T. and Roos, D., 1990. Machine that changed the world.

[3] Womack, J.P. and Jones, D. T. 1996. Beyond Toyota: how to root out waste and purse perfection. Harvard Business Review, 74, 140-172.

[4] Remon, F.A., and Hafex, S.M. 2013. Applying lean thinking in construction and performance improvement. Alexandria Engineering Journal 52(4), 679-695.

[5] Tomas.R, and Martin. J. 2014. Value Stream Mapping demonstration on real case study. Procedia Engineering 100, 520-529.

[6] Rahani A.R., and Muhammad A. 2012. Production flow analysis through value stream mapping: a lean manufacturing process case study. Procedia Engineering 41, 1727-1734.

[7] Jafri. M.R., and Seyed, M.Z. 2015. Production line analysis via value stream mapping: a lean manufacturing process of color industry. Procedia manufacturing 2, 6-10.

[8] Amir, A., and Thulasi, M. 2015. Designig a future value stream mapping to reduce lead time using SMED-a case study. 2015. Procedia Manufacturing 2, 153-158.

[9] David, A. and Federico,G. T.B. 2014. The value of lean in the service sector: a critique of theory \& practice. International Journal of Business and Social Science 5, 18-24.

[10] Gabriela S.S., Lili, m. and David, N. 2013. Lean principles in Healthcare: an overview of challenges and improvements. IFAC Proceedings Volumes 46, 229-234

[11]Moktadir, M. A., Ahmed, S., \& Fatema-Tuj-Zohra, S. R. (2017). Productivity improvement by work study technique: a case on leather products industry of Bangladesh. Ind. Eng. Manag., 6, 1-11.

[12] Bjorge, T.L., Acur, N., Boer, H., and Frick, j. 2005. Best manufacturing practices: what do the bestperforming companies do? 25(2), 131-150. 
[13]Ramachandran, A. and. Kesavan R. 2014. An application of lean manufacturing principle in automotive industry. Journal of Mechanical and Civil Engineering, 25-29.

[14] Cengiz, D., Aysel, C. and Yunus, E.A. 2015. Productivity improvement by work and time study technique for earth energy-glass manufacturing factory. Procedia Economics and Finance 26, 109113.

[15] Amol, N.P., and M, Prabhakaran. 2016. Labour productivity improvement by work study tools of fiber composite factory. International Journal of Research in Engineering and Technology 5, 351355.

[16] Moktadir, M. A., S. Ahmed, and Sultana R. Fatema-Tuj-Zohra. 2017. Productivity improvement by work study technique: a case on leather products industry of Bangladesh. Ind. Eng. Manage. 6, 1-11.

[17] Nonglucksana, N. 2015. Waste Reduction in Warehousing Process with LEAN Concept case study: Furniture Industry. Journal of Rajabhat Lampang University Management 2, 65-78.

[18] Patompong, H. and Jakraphan, K. 2012. Lean Production efficiency increasing : a case study of water pump manufacturing factory.Kasem Bundit Engineering Journal 2, 40-61.

[19] Pichet, P. and Sukarnda, S. 2013. Efficiency Increase in a Production Process of Wooden Furniture a case study: Indexinterfern Factory Limited. IE Network National Conference .563571.

[20] Sumit, K.S., Kuldeep, S., Deepak, K., and Tarun, G. 2014. Role \& Importance of Lean Manufacturing in Manufacturing Industry. The International Journal of Engineering and Science 3, 1-14.

[21] Abdul, T.B., and Tan, S.K. 2015. Implementation of Lean manufacturing for productivity improvement in Malaysia. In Industrial Engineering and Operations Management (IEOM), 2015 International Conference on (pp. 1-6). IEEE.

[22] Vincent, B., Kitty, K. and Monique, J. 2017. Identifying and eliminating inefficiencies in information system usage: A lean perspective. International journal of medical informatics, 107, 40-47.

[23] Rebecca, M. N., and Aile, T.A. 2015. Application of Lean Manufacturing Tools in a Garment Industry as a Strategy for Productivity Improvement. Asia

[24] Malihe, M., Mohd N.A., Che, R.C.M.Z. and Ezad, A.J. 2014. Increasing production and eliminating waste through lean tools and techniques for halal food companies. Sustainability, 6(12), 9179-9204.

[25] Kevin a., Darwin, A. and John, R. 2017. Towards Lean Manufacturing from Theory of Constraints: A Case Study in Footwear Industry. In Industrial Engineering, Management Science and Application (ICIMSA), 2017 International Conference on (pp. 1-8). IEEE.

[26] Jostein, P. 2009. Defining lean production: some conceptual and practical issues. The TQM Journal, 21(2), 127-142.

[27] Sharma, N., Matharou, G.S., Kaur, S., and Gupta, P. 2013. Lean manufacturing tool and techniques in process industry. International Journal of Scientific Research and Reviews, 2(1), 54-63.

[28] Rasi, R.Z.R., Rakiman, U.S. and Ahmad, M.F.B. 2015. Relationship between lean production and operational performance in the manufacturing industry. In IOP Conference Series: Materials Science and Engineering 83(1), 1-11.

[29] Ramdass, K. and Pretorius, L. 2008. Comparative assessment of process improvement methodologies: a case study in the South African clothing industry. In Engineering Management Conference, 2008. IEMC Europe 2008. IEEE International, p. 1-5. 